\title{
Environmental Health Graduates' Work Skills Competencies: Perspectives from the Employers and the Graduates
}

\author{
Hellen Jepngetich ${ }^{1}$, Kipkulei Japheth ${ }^{2}$, Caleb Nyamwange ${ }^{3}$, Joyce Baliddawa ${ }^{4}$ \\ ${ }^{1}$ Department of Environmental Health, School of Public Health, College of Health Sciences, Moi University, Eldoret, Kenya \\ ${ }^{2}$ Department of Haematology and Blood Transfusion, School of Medicine, College of Health Sciences, Moi University, Eldoret, \\ Kenya \\ ${ }^{3}$ Department of Biochemistry, School of Medicine, College of Health Sciences, Moi University, Eldoret, Kenya \\ ${ }^{4}$ Department of Behavioural Sciences and Ethics, School of Medicine, College of Health Sciences, Moi University, Eldoret, Kenya \\ Email: kenyhellen@yahoo.com
}

How to cite this paper: Jepngetich, $\mathrm{H}$., Japheth, K., Nyamwange, C. and Baliddawa, J. (2019) Environmental Health Graduates' Work Skills Competencies: Perspectives from the Employers and the Graduates. Health, 11, 182-194.

https://doi.org/10.4236/health.2019.112016

Received: January 15, 2019

Accepted: February 16, 2019

Published: February 19, 2019

Copyright $\odot 2019$ by author(s) and Scientific Research Publishing Inc. This work is licensed under the Creative Commons Attribution International License (CC BY 4.0).

http://creativecommons.org/licenses/by/4.0/

\begin{abstract}
Introduction: Environmental health is a rapidly evolving field, and professionals working in this field have to deal with increasingly complex environmental and public health concerns. Consequently, their skill development is a key component in ascertaining their abilities to match work requirements to the satisfaction of their employers. Training and education of these professionals requires involvement of the relevant stakeholders to apt their technical skills in preparation of the role to be undertaken. Thus, the universities and other institutions of higher learning, in their efforts to improve graduate output should understand the labor market. Additionally, due to constant transformation and reorganization of strategies and plans by practitioner organizations, employers' perspective in assessing graduates' abilities and performance is necessary. Aim: The purpose of this study was to assess the employers' perspectives on the graduates' abilities to handle work demands. Methods: A cross sectional descriptive study design involving employers and graduates of environmental health program of Moi University using mixed methods was carried out. Pre-tested semi structured paper questionnaires were administered to 45 employers, while online survey was carried out on 227 sampled graduates. In-depth interviews were further subjected to the graduates to corroborate issues raised. Quantitative data analysis was done using statistical package for social scientists (SPSS) version 20 where the data was summarized using frequencies and proportions. Qualitative data was thematically analyzed. Results: The overall employer assessment of the graduates' abilities to handle work demands was satisfactory with 18 (46.1\% 7 of
\end{abstract}


the employers rating them as good). On self-assessment, $116(61.7 \%)$ of the graduates reported not to have faced any skills competency challenge at their work place and only 57 (30.3\%) reported adequacy in skills acquired during undergraduate training. From the in-depth interviews, the graduates applauded the current curriculum implementation strategy of Problem Based Learning (PBL) but faulted the infrastructural inadequacies for low competencies and inadequate skills. The in-depth interviews further revealed a picture of graduates struggling with skills' mismatch in their job placement. Conclusion: The study revealed a good rating by employers on the graduates' competency skills but a high proportion (69.7\%) of graduates reported lack of adequate skills to match their work demands. Recommendations: Institutions of higher learning need to invest in infrastructural elements of curriculum implementation to boost more practical sessions for better skills' acquisition that matches the industrial needs.

\section{Keywords}

Environmental Health, Graduates, Employer, Perspectives \& Work Demands

\section{Introduction}

Public health workforce is vital for protecting the safety of the public. The development of a fully competent public health workforce is a key component of the nation's public health. It is also critical to the improvement of population health globally. However, there is a growing rate of unemployment among university graduates, yet employers are lamenting on their inability to get skilled workforce for hire [1]. This has raised a heated debate across the globe on the quality of graduates being trained and released into the job market. One of the factors singled out for graduate unemployment in Kenya is an increasing mismatch between education skills, practical and the domains of the job market [2]. This has led to the mounting increase in global concerns and the campaigns for the need for competent public health workforce that is responsive to the ever-changing public health complexities [3]. This indeed is an aspect of quality assurance and high competency training also advocated for by the Kenyan Commission for University Education (CUE) established in 2012 under the Universities Act No. 42 of 2012 as a successor to the Commission for Higher Education in Kenya. This commission is mandated to regulate University Education to ascertain quality education for national, regional and global competitiveness [4] [5]. The Kenyan Commission for Higher Education (CUE) has been trying to tackle the quality crisis seen in Kenyan universities by undertaking sweeping reviews, crackdowns and other forms of quality audits. Despite all these measures, a host of questionable practices affecting the quality of the Kenya's rapidly expanding higher education sector and that of its graduates still exists [4] [6] [7].

As the global university enrolment rate soars high, graduates from Kenyan 
universities have increased from 25,523 in 2012 to 49,020 in 2015 [8]. This rapid increase is however not corresponding to their abilities to undertake work requirements. A study by the interuniversity council of East Africa revealed that more than $50 \%$ of the graduates are poorly prepared for the job market with Kenyan graduates ranging the highest at $67 \%$. This raises serious concerns for the various academic institutions in their continued journey of training and generating graduates into the labor market. It is well known that these institutions of higher learning use varying curriculum as well as varying curriculum implementation strategies. Whereas the curricula vary for the different academic institutions, what is less clear is whether what is taught matches the competency requirements for the real world work requirements [9]. Several other studies and annual reviews on outcome based workforce development in public health have placed higher hopes on a successful academic-practical partnership to improved public health outcomes [10] [11]. If industries are encouraged to continuously give feedback to academic institutions on graduate trainee's assessment, a key aspect of targeted training would be institutionalized and could eventually revolutionize graduate outcomes [1] [12]. This study sought to determine the employer's perspectives on the graduates' abilities to handle work demands. The graduates' self-assessment on the adequacy of the competencies acquired during their training, the competency challenges faced as well as their career placements were also explored.

\section{Materials and Methods}

\subsection{Study Design}

A cross sectional study using both quantitative and qualitative methods was used.

\subsection{Study Site}

The study was based at the Department of Environmental Health, Moi University, and College of Health Sciences.

\subsection{Study Population}

The study population encompassed B.Sc. Environmental Health graduates and their respective employers in the various practitioner organizations.

\subsection{Study Sample and Target}

The study targeted a sample of 227 graduates and 45 employers. Graduates who had graduated from the school of public, Moi University from the year 1999 to 2015 were targeted. For the in-depth interviews, saturation level was reached at graduate number 22 .

To get the graduates desired sample size, the Cochran's formula was used as follows;

$$
n=z^{2} p q / d^{2}
$$


where:

$n=$ The desired sample size.

$Z=$ the corresponding value confidence level of $95 \%$ in the normal distribution table.

$\mathrm{P}=$ the proportion in the target population whose training matchs the workforce demands (used $60 \%$ as per the healthcare competency research done by Quality assurance project in Kenya) [13].

$q=1-p$.

$d=$ the amount of discrepancy to correlate in $p$. It was set at 0.05 .

$n=1.96^{2} \times 0.6 \times 0.4 / 0.05^{2}=368$.

Since the population under study was less than 10,000, then the sample size of the B.Sc. graduates was adjusted using Fischer Exact formula used for calculating sample sizes for population sizes less than 10,000 as below;

$$
n=n_{0} /\left(1+\left(\left(n_{0}-1\right) / N\right)\right)
$$

where:

$n$-the adjusted sample size.

$n_{0}$-the calculated sample size from the Cochran's formula (368).

$\mathrm{N}$-The population size (600).

$$
\begin{aligned}
n & =368 /(1+367 / 600) \\
& =227
\end{aligned}
$$

The employer organizations were mapped using the existing EVH alumni register versus their placement to establish the highest absorber of the graduates. A total of 45 practitioner organizations were targeted who had employed at least 2 graduates.

\subsection{Sample Size Selection}

The graduates were stratified by year of graduation and sex then proportionately recruited using simple random sampling. The employers were purposively recruited.

\subsection{Inclusion Criteria}

\subsubsection{Graduates}

The graduates must have graduated between the years 1998 and 2015, both years inclusive and have ever worked for least six months after qualifying from the university.

\subsubsection{Employers}

The employers must be employees of any practitioner organizations employing BSc. EVH graduates. They should have been involved in supervision of the graduates.

\subsection{Exclusion Criteria}

Graduates working outside Kenya were excluded whereas employers who have 
not supervised graduates for at least six months were excluded.

\subsection{Data Collection Methods and Tools}

A pretested semi structured questionnaire was used to collect data from the graduates and the employers. The interviews with the graduates were carried out by administration of the questionnaires via an online survey while the one with the employers was self-administered. With this, appointments were made; a questionnaire was then delivered and collected at an agreed date and time.

The questionnaires had information to capture demographic (age, sex etc.) data of the graduates and the employer respondents. It also contained Likert scale items to assess the graduate's skills competencies as per the job requirements by the employers. Other items in the questionnaire dealt with the graduate's perception of the adequacy of their skills obtained during undergraduate training in preparation for the work demands.

For in-depth interviews, the graduates were subjected to oral questioning using open ended questions until saturation level was achieved. An audio recorder was used during the interviews and later transcribed. The saturation level was achieved at graduate number 22 .

\subsection{Data Management and Analysis}

Quantitative data was analyzed using SPSS version 20 whereby data was summarized using frequencies and proportions. Qualitative findings in-depth interviews were transcribed into written words and used for narrations.

In assessing the graduates' performance by their employers, the core competency skills for the broad practice of public health were adopted from the Council on Linkages between Academia and public health practice [14]. The skills assessed ranged from analytic/assessment skills to the job knowledge. Each core competency item that the employers used to assess the graduates' performance was evaluated using a Likert scale of 1 - 4 where 1-“Poor", 2-"Fair", 3-“Good", 4- "Excellent". The frequencies of the scale responses per item were totaled and proportions calculated.

\subsection{Ethical Considerations}

Ethical approval was obtained from Institutional Research and Ethics Committee (IREC, a College of Health Sciences), Moi University and the Moi Teaching and Referral Hospital committee. Informed consent was sought from all the participants. Participation was voluntary and the information provided was treated with confidentiality and anonymity.

\section{Results}

\subsection{Graduates Demographic Characteristics}

Of the 227 graduates sampled for the study, 188 completed the questionnaires, giving a response rate of $82.8 \%$. The Among 188 graduates that completed the 
questionnaires, 79 (42\%) were aged 25 - 34 years, 71 (37.8\%) aged 35 - 44 years, $29(15.4 \%)$ aged $45-54$ and $9(4.8 \%)$ were $\leq 25$ years. More than half 111 (59\%) of the graduates were males.

\subsection{Graduates Career Placements}

The graduates were distributed over more than 12 public health career areas. These included disaster preparedness and management 33 (17.6\%), research 27 (14.4\%), community health $16(8.5 \%)$ and Infection prevention $16(8.5 \%)$. There was also a category of other careers (17\%) and included those who were running consultancy companies, working in private enterprise, and others based at the banks as banks clerk. The career distribution is as depicted in Figure 1.

\subsection{Graduates Perceptions of Their Competencies to Handle Work Demands}

Of all the graduates interviewed, 142 (75.5\%) reported that their undergraduate training formed the basis for their current job. On the other hand, only 57 $(30.3 \%)$ reported adequacy in their skills acquired during undergraduate training and $72(38.2 \%)$ of the graduates intimated that they had faced competency challenges at their work place.

The results from the in-depth interviews portrayed a mixed picture about the role played by their training in determining their competencies, with negative narrations from those who reported competency challenges and praises from those who had not faced competency challenges as exemplified from the narrations below;

“... regrettably nobody mentioned strategies like PHASE, PHAST, CLTS, MHM etc. which are common WASH terms ... in fact, my employer wondered what kind of public health I had done ..."

39 years old female

“... well for me the program is excellent and I enjoy applying the skills out here ... the department just needs to improve on the weak areas like practical orientation aspects..."

35-year-old male.

“... need to review the curriculum to be up to date with the requirements of the job market; personally, I had to learn some aspects on job ..."

34-year-old Male.

\subsection{Demographic Characteristics of the Employer Respondents}

Out of the sampled 45 employers, 39 responded giving a response rate of $86.6 \%$. Among the 39 employer respondents who participated in the study, 16 (41.0\%) were aged between 50 - 59 years and 27 (69.2\%) were male. Eleven (28.2\%) of the employer respondents were field supervisors and the same number had worked for 2 - 5 years with the same employer. The details of the employer respondent demographic characteristics are shown in Table 1. 


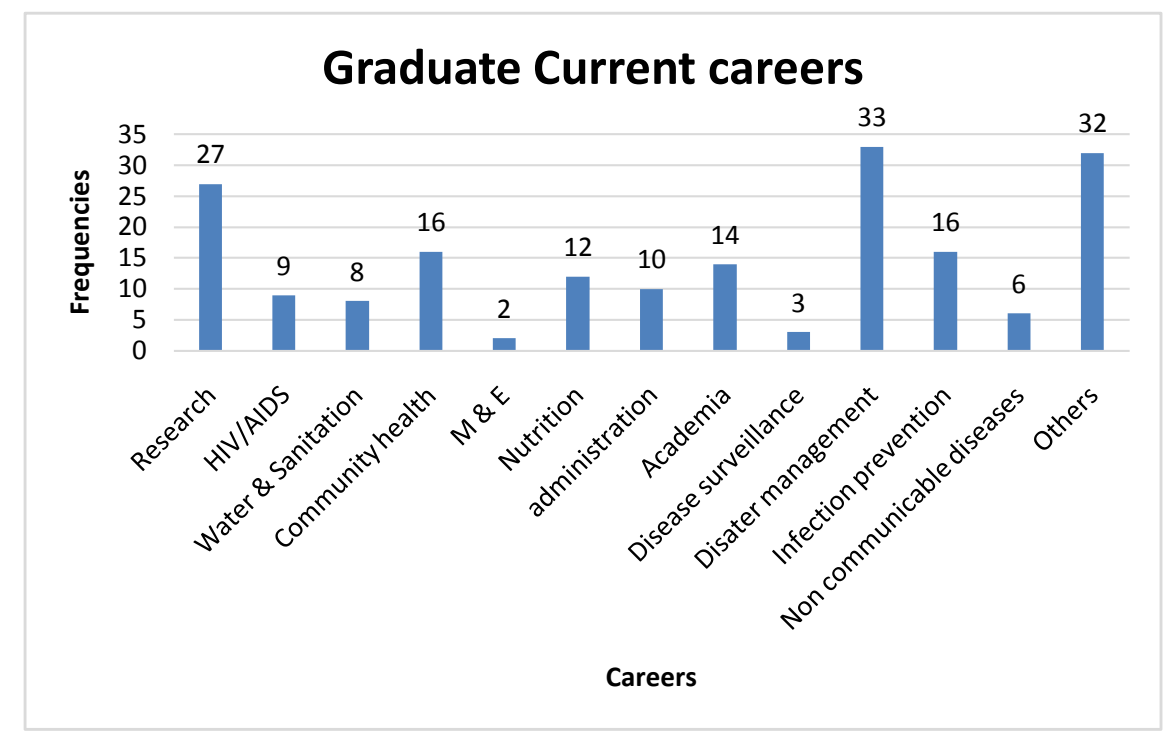

Figure 1. Distribution of graduate career placements.

Table 1. Demographic characteristics of the employer respondents.

\begin{tabular}{|c|c|c|}
\hline Characteristic & Frequency (n) & Percent \\
\hline \multicolumn{3}{|l|}{ Age-group (years) } \\
\hline $30-39$ & 8 & 20.5 \\
\hline $40-49$ & 10 & 25.6 \\
\hline $50-59$ & 16 & 41.0 \\
\hline$\geq 60$ & 5 & 12.8 \\
\hline \multicolumn{3}{|l|}{ Gender } \\
\hline Male & 27 & 69.2 \\
\hline Female & 12 & 30.8 \\
\hline \multicolumn{3}{|c|}{ Current position in the organization } \\
\hline Head of department & 6 & 15.4 \\
\hline Human resource manager & 2 & 5.1 \\
\hline Field Supervisor & 11 & 28.2 \\
\hline Program manager & 3 & 7.7 \\
\hline Administrator & 9 & 23.1 \\
\hline Others & 8 & 20.5 \\
\hline \multicolumn{3}{|c|}{ Duration worked with current institution } \\
\hline$<2$ years & 10 & 25.6 \\
\hline $2-5$ years & 11 & 28.2 \\
\hline $5-10$ years & 9 & 23.1 \\
\hline$>10$ years & 9 & 23.1 \\
\hline
\end{tabular}

\subsection{Employers' Perspectives on Graduates Performance on Assigned Tasks}

On specific competency ratings, $20(51.3 \%)$ of the employers rated graduates as 
excellent on meeting timelines and being team players. Employers also rated graduates as good in planning and organizational skills 21 (53.8\%), analytic and assessment skills 19 (48.7\%) as well as in practical and technical skills. There was however, a significant proportion of employers who rated the graduates' communication skills as fair $(30.8 \%)$. The overall mean score of the competencies was 3.30 with a standard deviation of 0.24 . The employer rating of graduate's skills competencies is as shown in Table 2.

\subsection{Employer Respondent Characteristics and the Assessment of Graduate's Skills Competencies}

Analysis of the relationship between the graduates skills competency scores and the employer characteristic showed that, there was a statistically significant difference in the competency scores between the positions of the employer respondents $(\chi 2=12.916 ; p=0.024)$. The mean rank scores were higher among the category under others (26.31) and lower among program managers (6.67) as shown in Table 3.

\section{Discussion}

Findings from the study indicate that more than half of the employers 24 $(61.5 \%)$ indicated that the environmental health graduates employed in their organizations had no challenges in their skills competencies. This finding is similar to the findings of a study done in Malaysia on Malaysian graduates' employability skills where employers who had hired graduates from Malaysian universities were satisfied and happy with the graduates from these universities [15]. On the hand, $116 / 188(61.7 \%)$ of the graduates reported that they did not face any competency challenges in their work place. This finding is consistent with those of a study done by Prince et al. [16] where junior doctors transitioning from medical school to clinical practice in the Netherlands reported that their undergraduate training was adequate in terms of skills acquisition that boosted their confidence in clinical practice. There was a significant proportion of employers (38.5\%) reporting that environmental health graduates face skills competency challenges and a similar proportion $(38.3 \%)$ of the graduates self-reporting inadequacies in their skills competencies. These findings in addition to only $30.3 \%$ of the graduates reporting adequacy in skills acquired during undergraduate training could be postulated to be as a result of a disconnect of key training needs between the higher education and the world of work and this calls for concerted efforts from all the concerned stake holders to remedy the situation. With a substantive proportion of employers reporting graduates' competency challenges at their job placement, it seems the reliance upon the new graduates to foster innovative practices in organizations is fading away [17]. Graduates competency challenges have been associated with several factors during their course of training as well as skills change [18].

Despite these competency challenges being alluded to the constant change of skills requirement by employers, there is need to explore the development of 
Table 2. Employer rating of graduate's skills competencies.

\begin{tabular}{|c|c|c|c|c|c|c|c|c|}
\hline \multirow{2}{*}{ Item } & \multicolumn{4}{|c|}{ Frequencies (\%) } & \multirow{2}{*}{ Mean (SD) } & \multirow{2}{*}{ Median } & \multirow{2}{*}{ Min-Max } & \multirow{2}{*}{$P$ value } \\
\hline & Poor & Fair & Good & Excellent & & & & \\
\hline $\begin{array}{c}\text { Analytic and } \\
\text { assessment skills }\end{array}$ & 2.6 & 17.9 & 48.7 & 30.8 & $3.09(0.77)$ & 3 & $1-4$ & 0.055 \\
\hline $\begin{array}{c}\text { Planning and } \\
\text { organization skills }\end{array}$ & 0 & 12.8 & 53.8 & 33.3 & $3.21(0.66)$ & 3 & $2-4$ & 0.225 \\
\hline $\begin{array}{l}\text { Communication } \\
\text { skills }\end{array}$ & 0 & 30.8 & 38.5 & 30.8 & $3.00(0.79)$ & 3 & $2-4$ & 0.004 \\
\hline $\begin{array}{l}\text { Practical and } \\
\text { technical skills }\end{array}$ & 0 & 15.4 & 48.7 & 35.9 & $3.21(0.70)$ & 3 & $2-4$ & $<0.001$ \\
\hline $\begin{array}{l}\text { Quality of work } \\
\text { by the graduate }\end{array}$ & 0 & 10.3 & 48.7 & 48.7 & $3.38(0.67)$ & 3 & $3-4$ & 0.282 \\
\hline $\begin{array}{l}\text { Completes } \\
\text { assigned tasks } \\
\text { on time }\end{array}$ & 0 & 0 & 48.7 & 51.3 & $3.51(0.51)$ & 4 & $3-4$ & 0.142 \\
\hline Meeting timelines & 0 & 5.1 & 43.6 & 51.3 & $3.46(0.60)$ & 4 & $2-4$ & 0.591 \\
\hline Team player & 0 & 46.2 & 35.9 & 17.9 & $3.51(0.51)$ & 4 & $3-4$ & 0.018 \\
\hline
\end{tabular}

Note. $\mathrm{N}=39$. Scale: $1=$ poor, $2=$ fair, $4=$ excellent.

Table 3. Employer respondent characteristics and the assessment of graduate's skills competencies.

\begin{tabular}{|c|c|c|c|c|}
\hline Characteristic & $\mathbf{N}$ & Mean Rank & Test statistic & p-value \\
\hline \multicolumn{5}{|l|}{ Age (years) } \\
\hline $30-39$ years & 8 & 15.25 & \multirow{4}{*}{$2.105^{\mathrm{a}}$} & \multirow{4}{*}{0.551} \\
\hline $40-49$ years & 10 & 22.80 & & \\
\hline $50-59$ years & 16 & 20.53 & & \\
\hline $60-69$ years & 5 & 20.30 & & \\
\hline \multicolumn{5}{|l|}{ Sex } \\
\hline Male & 26 & 19.67 & \multirow{2}{*}{$0.258^{\mathrm{b}}$} & \multirow{2}{*}{0.797} \\
\hline Female & 13 & 20.65 & & \\
\hline \multicolumn{5}{|l|}{ Position in the organization } \\
\hline Head of department & 6 & 10.00 & \multirow{6}{*}{$12.916^{\mathrm{a}}$} & \multirow{6}{*}{0.024} \\
\hline Human resource manager & 2 & 20.75 & & \\
\hline Field Supervisor & 11 & 23.86 & & \\
\hline Program manager & 3 & 6.67 & & \\
\hline Administrator & 9 & 20.61 & & \\
\hline Others & 8 & 26.31 & & \\
\hline \multicolumn{5}{|l|}{ Number of years worked } \\
\hline$<2$ years & 10 & 22.05 & \multirow{4}{*}{$6.278^{\mathrm{a}}$} & \multirow{4}{*}{0.099} \\
\hline $2-5$ years & 11 & 21.82 & & \\
\hline 5 - 10 years & 9 & 11.89 & & \\
\hline$>10$ yeas & 9 & 23.61 & & \\
\hline
\end{tabular}

a-Kruskal-Wallis; b-Mann Whitney. 
employability agenda in higher education and examine implications of organizational change for graduates while assessing the attributes that graduates will need in their next phase of job placement [19] [20]. As this debate rages on, higher education institutions must be well informed of the graduate's expectations from the world of work in order to adopt the proactive role in responding to preparing graduates to face future job tasks, new employment patterns and contributions to innovative society [21].

On specific competency ratings, 20 (51.3\%) of the employers rated graduates as excellent on meeting timelines and being team players. This group of graduates in terms of competency and individual performance need to be commented for continued performance. As Kurtz and team asserts in their study on modelling the world of work, excellent performers over time decline dramatically due to organizational culture [22]. However, due to the current public health practice, public health graduates ought to maintain their public health knowledge on the most recent advances of public health and attending CPD programs is one way of refreshing knowledge and remaining current.

The results of the current graduates' career placement revealed mixed expectations. The leading graduates' career was disaster management, followed closely with the careers grouped as others. Although disaster management, is an expected outcome of the degree program training, the career grouped 'others' raised some concerns. The graduates' careers under 'others' included running of consultancy firms, entrepreneurship, banking and leadership in financial corporations. This finding could suggest some aspect of graduates' competency challenges and hence their subsequent choices to undertake less stressful tasks as were found out by Walsh et al., [23] on their study on core competencies for disaster medicine and public health. The finding could also mean that there is no sufficient market for the Bachelor of Science environmental health graduates and therefore opting to take up any other job available to earn a living. The study by Walsh et al., [23] showed that despite being trained, public health graduates lacked critical knowledge and experience to operate under stressful conditions thereby resorting to other comfortable career options. Our study seem to point out some training gaps which could be identified as professional training needs and ploughed back to the graduates' curriculum for better workforce development as suggested by Aslam and team [24].

\section{Conclusion}

The study showed that the environmental health graduates' skills competencies were good as assessed by the employers and the employers also noted that the majority of the graduates employed in their organizations had faced no skills challenges in their place of work. A significant proportion of the graduates reported that they faced competency challenges and lacked adequate skills to match their work demands. This inadequacy in skills could be an indicator of lack of practical experiences due to theoretical trainings and very limited field exposures. The curriculum content and scope should be expanded to meet the 
changing technological skill needs of the job market. For well-rounded training, institutions of higher learning should establish linkages and collaboration to enhance professional skills as well as well-developed workforce meeting industry demands.

\section{Acknowledgements}

The research was supported by the Consortium for Advanced Research Training in Africa (CARTA). CARTA is jointly led by the Africa Population and Research Centre (APHRC) and the University of Witwatersrand. CARTA is jointly led by the African Population and Health Research Center and the University of the Witwatersrand and funded by the Carnegie Corporation of New York (Grant No-B 8606.R02), Sida (Grant No: 54100029), the DELTAS Africa Initiative (Grant No: 107768/Z/15/Z). The DELTAS Africa Initiative is an independent funding scheme of the African Academy of Sciences (AAS)'s Alliance for Accelerating Excellence in Science in Africa (AESA) and supported by the New Partnership for Africa's Development Planning and Coordinating Agency (NEPAD Agency) with funding from the Wellcome Trust (UK) and the UK government. The statements made and views expressed are solely the responsibility of the fellow.

\section{Conflicts of Interest}

The authors declare no conflicts of interest regarding the publication of this paper.

\section{References}

[1] Tóth-Téglás, T., Hlédik, E. and Fónadová, L. (2016) An Analysis of Employer Requirements of University Graduates. Acta Polytechnica Hungarica, 13, 169-188.

[2] Nyerere, J. (2009) Technical and Vocational Education and Training (TVET) Sector Mapping in Kenya. Edukans Foundation, Amersfoort.

[3] Conejero, J.S., Godue, C., Gutierrez, J.F., Valladares, L.M., Rabionet, S., Concha, J., et al. (2013) [Core Competencies in Public Health: A Regional Framework for the Americas]. Rev Panam Salud Publica, 34, 47-53.

[4] Odhiambo, G.O. (2011) Higher Education Quality in Kenya: A Critical Reflection of Key Challenges. Quality in Higher Education, 17, 299-315. https://doi.org/10.1080/13538322.2011.614472

[5] Abagi, O., Nzomo, J., Otieno, W. and Varghese, N. (2005) Private Higher Education in Kenya: International Institute for Educational Planning.

[6] Munene, I. (2016) Kenya's Universities Are in the Grip of a Quality Crisis. Retrieved February, 22, 2017.

[7] Owuor, N.A. (2012) Higher Education in Kenya: The Rising Tension between Quantity and Quality in the Post-Massification Period. Higher Education Studies, 2, 126-136. https://doi.org/10.5539/hes.v2n4p126

[8] Wiesmann, U.M., Kiteme, B. and Mwangi, Z. (2014) Socio-Economic Atlas of Kenya: Depicting the National Population Census by County and Sub-Location: Kenya National Bureau of Statistics, Centre for Training and Integrated Research in ASAL Development, Centre for Development and Environment. 
[9] Whittaker, P.J., Pegorie, M., Read, D., Birt, C.A. and Foldspang, A. (2010) Do Academic Competencies Relate to "Real Life" Public Health Practice? A Report from Two Exploratory Workshops. European Journal of Public Health, 20, 8-9. https://doi.org/10.1093/eurpub/ckp157

[10] Koo, D. and Miner, K. (2010) Outcome-Based Workforce Development and Education in Public Health. Annual Review of Public Health, 31, 253-269. https://doi.org/10.1146/annurev.publhealth.012809.103705

[11] Hoge, M.A., Paris, M., Adger, H., Collins, F.L., Finn, C.V., Fricks, L., et al. (2005) Workforce Competencies in Behavioral Health: An Overview. Administration and Policy in Mental Health and Mental Health Services Research, 32, 593-631. https://doi.org/10.1007/s10488-005-3259-x

[12] Ho, H.-F. (2015) Matching University Graduates' Competences with Employers' Needs in Taiwan. International Education Studies, 8, 122. https://doi.org/10.5539/ies.v8n4p122

[13] Mutungi, A., Harvey, S., Kibaru, J., Lugina, H., Kinoti, S., Jennings, L., et al. (2008) Kenya: Assessment of Health Workforce Competency and Facility Readiness to Provide Quality Maternal Health Services. United States Agency for International Development. https://www.usaidassist.org/sites/assist/files/kenya_sba_withcover.pdf

[14] Academia, C.O.L.B. and Practice, P.H. (2010) Core Competencies for Public Health Professionals. Public Health Foundation, Washington, DC.

[15] Singh, G.K.G. and Singh, S.K.G. (2008) Malaysian Graduates' Employability Skills. UNITAR E-Journal, 4, 15-45.

[16] Prince, K., Van de Wiel, M., Van der Vleuten, C., Boshuizen, H. and Scherpbier, A. (2004) Junior Doctors' Opinions about the Transition from Medical School to Clinical Practice: A Change of Environment. Education for Health, 17, 323-331.

[17] Jackson, D. (2010) An International Profile of Industry-Relevant Competencies and Skill Gaps in Modern Graduates. International Journal of Management Education, 8, 29-58.

[18] Chauvin, S.W., Anderson, A.C. and Bowdish, B.E. (2001) Assessing the Professional Development Needs of Public Health Professionals. Journal of Public Health Management and Practice, 7, 23-37. https://doi.org/10.1097/00124784-200107040-00005

[19] Hesketh, A.J. (2000) Recruiting an Elite? Employers' Perceptions of Graduate Education and Training. Journal of Education and Work, 13, 245-271. https://doi.org/10.1080/713676992

[20] Harvey, L. (2000) New Realities: The Relationship between Higher Education and Employment. Tertiary Education \& Management, 6, 3-17. https://doi.org/10.1080/13583883.2000.9967007

[21] Teichler, U. (1999) Higher Education Policy and the World of Work: Changing Conditions and Challenges. Higher Education Policy, 12, 285-312. https://doi.org/10.1016/S0952-8733(99)00019-7

[22] Kurz, R. and Bartram, D. (2002) Competency and Individual Performance: Modelling the World of Work. In: Robertson, I.T., Callinan, M. and Bartram, D., Eds., Organizational Effectiveness. The Role of Psychology, John Wiley \& Sons, Ltd., Hoboken, 227-255. https://doi.org/10.1002/9780470696736.ch10

[23] Walsh, L., Subbarao, I., Gebbie, K., Schor, K.W., Lyznicki, J., Strauss-Riggs, K., et al. (2012) Core Competencies for Disaster Medicine and Public Health. Disaster Medicine and Public Health Preparedness, 6, 44-52. https://doi.org/10.1001/dmp.2012.4 
[24] Aslam, S., Delgado-Angulo, E. and Bernabé, E. (2017) Perceived Learned Skills and Professional Development of Graduates from a Master in Dental Public Health Programme. European Journal of Dental Education, 21, 1-5.

https://doi.org/10.1111/eje.12167

\section{List of Abbreviations}

CLTS: Community Led Total Sanitation;

MHM: Menstrual Hygiene Management;

PHAST: Participatory Hygiene and Sanitation Transformation;

WASH: Water, Sanitation and Hygiene. 